Zoologica Poloniae (2008) 53/1-4: 19-25

$10.2478 / \mathrm{v} 10049-008-0002-7$

\title{
ULTRASTRUCTURE OF THE MIDGUT EPITHELIUM IN DACTYLOBIOTUS DISPAR (TARDIGRADA: EUTARDIGRADA) DURING ENCYSTATION
}

\author{
Magdalena M. Rost-Roszkowska and Izabela Poprawa
}

Department of Animal Histology and Embryology, University of Silesia, Bankowa 9, 40-007 Katowice, Poland, phone: +48 32 3591376,

e-mail: magdalena.rost-roszkowska.@us.edu.p1, izabela.poprawa@us.edu.pl

\begin{abstract}
Tardigrada are invertebrates which are able to survive unfavorable conditions of the environment by e.g. encystation. Histolysis of the animal tissues during encystation has been suggested for many species of Tardigrada, while it has not been observed in Dactylobiotus dispar. The midgut epithelium plays a role in digestion, secretion, absorption and even in osmoregulation. During encystation in $D$. dispar the digestion is inhibited, and the midgut lumen is devoid of nourishment. Numerous lipid droplets, vesicles, and multivesicular bodies accumulate in the cytoplasm of epithelial cells. We described the ultrastructure of the midgut epithelium in encysted specimens of D. dispar.
\end{abstract}

Key words: Tardigrada, encystation, midgut, midgut epithelium

\section{INTRODUCTION}

Tardigrada (water bears) are small, segmented animals closely related to the arthropods. They are widespread in terrestrial, freshwater and marine habitats (Dewel et al., 1993; Kinchin, 1994). The water bears are able to survive in extreme environments that would kill almost any other animal. They can survive temperatures close to absolute zero and temperatures as high as $150^{\circ} \mathrm{C}$. Tardigrada can withstand 570,000 rads of x-radiation (MAY, 1948). Many species are capable of forming resistant cysts. Encystation protects them against unfavorable effects of environmental conditions (Węglarska, 1957; SzYMAŃSKA, 1995). Metabolism in cysts is higher than that observed in tuns, but much lower than that described in active animals (Pigoń and WęGLARSKA, 1953). Early observations on 
cysts suggested complete histolysis of the animal tissues (Murray, 1907; Heinis, 1910). According to WęglarsKa (1957) such histolysis did not occur during encystation in $D$. dispar.

Information on the ultrastructure of the midgut epithelium in Tardigrada is rather scanty and it mainly refers to active animals. It remains unkown what processes take place in the midgut epithelial cells of encysted specimens. Therefore the aim of our study was to analyze the ultrastructure of the midgut epithelium of $D$. dispar cysts.

\section{MATERIAL AND METHODS}

The animals for investigation originated from the laboratory culture of D. dispar (Murray, 1907) (Tardigrada: Eutardigrada). Cysts were fixed in $2.5 \%$ glutaraldehyde in $0.1 \mathrm{M}$ phosphate buffer at $\mathrm{pH} 7.4\left(2 \mathrm{~h}\right.$ at $\left.4{ }^{\circ} \mathrm{C}\right)$ and postfixed in $1 \% \mathrm{OsO}_{4}(2 \mathrm{~h}$ at room temperature). After dehydration in alcohol series $(50 \%$, $70 \%, 90 \%, 95 \%$, and $100 \%$, each for $15 \mathrm{~min}$ ) and acetone (15 min) the material was embedded in Epon 812. Semi- and ultra-thin sections were cut on a Leica Ultracut UCT25 ultramicrotome. Semi-thin sections were stained with $1 \%$ methylene blue in 1\% borax and examined with an OLYMPUS BX60 light microscope. Ultra-thin sections were stained with uranyl acetate and lead citrate. They were examined with a Hitachi H500 transmission electron microscope.

Cysts after fixing with $2.5 \%$ glutaraldehyde $(2 \mathrm{~h})$, postfixing with $2 \% \mathrm{OsO}_{4}$ $(2 \mathrm{~h})$, and dehydration in a graded series of alcohols $(30,50,70,80,90,95$, and $100 \%$ each for $10 \mathrm{~min})$ and acetone $(10 \mathrm{~min})$, were dried at critical point Pelco CPD2 and coated with gold in a Pelco SC-6 duster. These preparations were examined with a Tesla BS340 scanning electron microscope.

\section{RESULTS}

Midgut of encysted specimens of D. dispar (Fig. 1) is situated centralventrally. The ovary adheres to its dorsal side. The lumen of the midgut, devoid of nourishment, is extremely narrow (Fig. 2). Therefore pro-, meso- and metamesenteron are not distinguishable.

Midgut epithelium is composed only of epithelial cells. Regenerative cells are not present. Basal membrane of epithelial cells forms numerous folds with

Figs 1-6. Encystation in Dactylobiotus dispar.

Fig. 1. Cyst of D. dispar - ventral view. SEM, bar $=53 \mathrm{~mm}$.

Figs. 2 and 3. Midgut epithelium. Lumen of the midgut $(\mathrm{ml})$ is extremely narrow and devoid of nourishment. Microvilli (mv), lipid droplets (1), rough endoplasmic reticulum (RER). Fig. 2. TEM, bar $=1.21 \mathrm{~mm}$, Fig. 3. TEM, bar $=0.63 \mathrm{~mm}$.

Fig. 4. Part of the midgut epithelium cell. Nucleus (n), nucleolus (nu), rough endoplasmic reticulum (RER), smooth endoplasmic reticulum (SER), Golgi complexes (d), lipid droplets (1). TEM, bar $=0.61 \mathrm{~mm}$. 

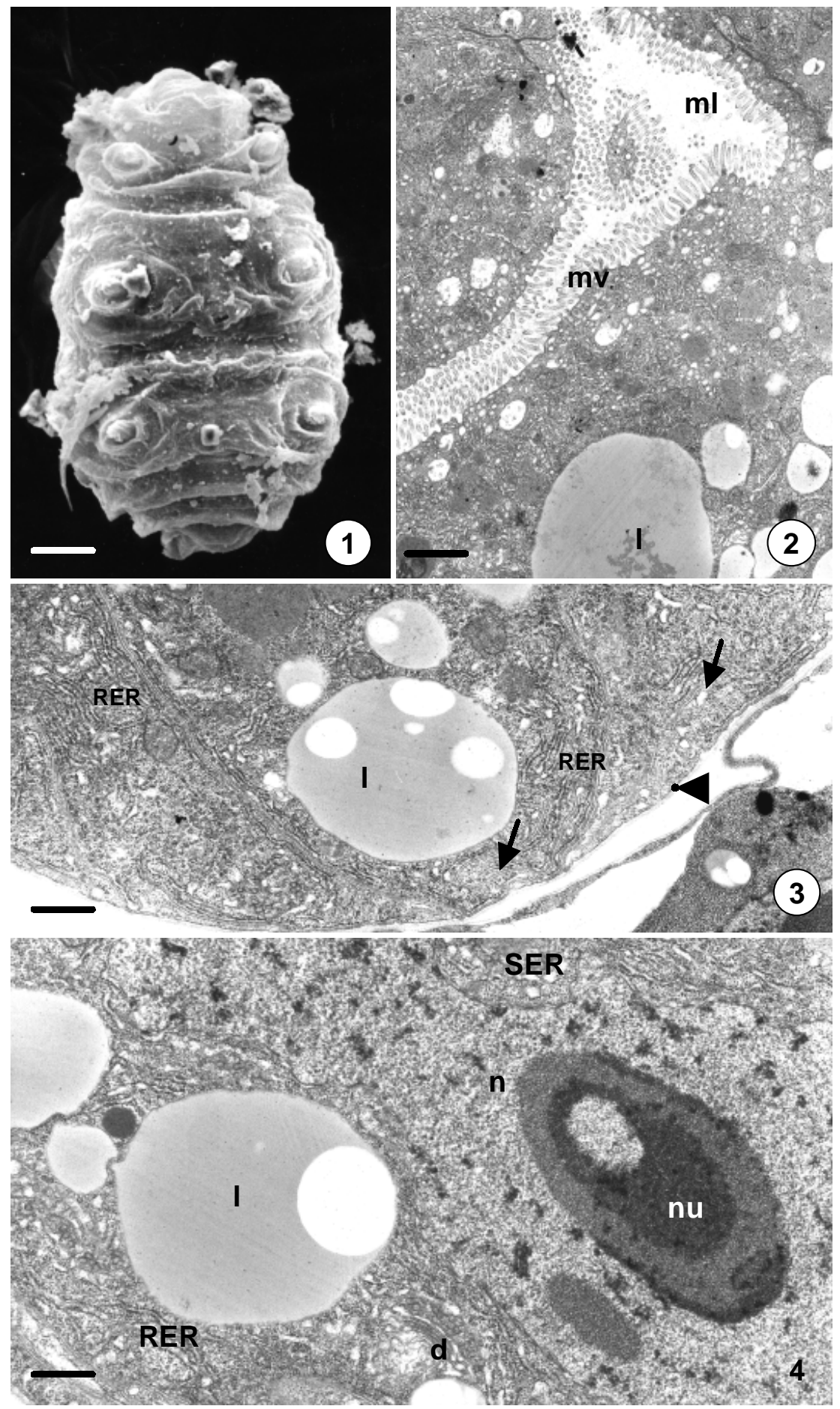


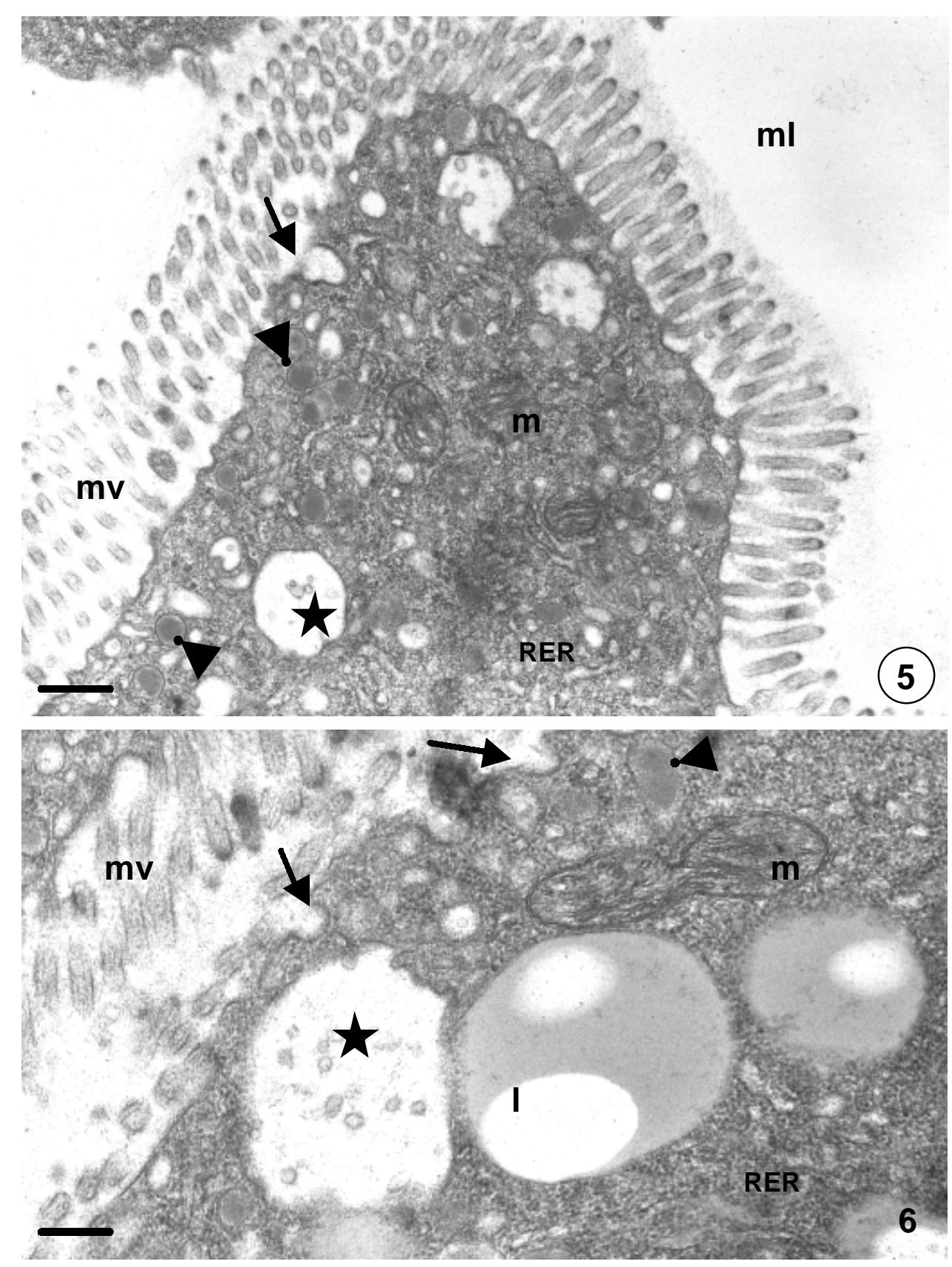

Figs. 5 and 6. The apical region of the midgut epithelium cell. Vesicles with electron dense content (arrowheads), large vacuoles resembling multivesicular bodies (asterisk), mitochondria (m), lipid droplets (1), microvilli (mv). Fig. 5. TEM, bar $=0.52 \mathrm{~mm}$, Fig. 6. TEM, bar $=0.29 \mathrm{~mm}$. 
many cisterns of rough endoplasmic reticulum and free ribosomes among them (Fig. 3). In the perinuclear cytoplasm, numerous Golgi complexes and abundant rough and smooth endoplasmic reticulum occur. The nucleus assumes a lobular shape and possesses heterogenic nucleolus (Fig. 4). The apical cytoplasm is poor in cisterns of endoplasmic reticulum, but it is rich in small vesicles of electron lucent content. Such vesicles open into the midgut lumen, where they discharge their contents (Fig. 5). The vesicles of electron dense interior and large vacuoles resembling multivesicular bodies (Figs. 5, 6) are also present in the apical cytoplasm. Apical membrane forms numerous microvilli, which protrude into the narrow midgut lumen. The entire cytoplasm is rich in lipid droplets of different size, but there are only few mitochondria.

\section{DISCUSSION}

The alimentary tract of Tardigrada is composed of foregut, midgut and hindgut (Pirch and Greven, 1994). The midgut is the region responsible for digestion, secretion and additionally - in Heterotardigrada - for excretion and osmoregulation (Greven, 1976; Dewel et al., 1988, 1993).

The midgut epithelium of analyzed species of Tardigrada is formed by epithelial cells placed on the non-cellular basal lamina (Kristensen, 1976; PirCH and Greven, 1994; Avdonina et al., 2007). No regenerative cells were described (Greven, 1976), but some studies revealed that the crescent-like cells of the anterior midgut were able to proliferate (BERTOLANI, 1970). In many water bears epithelial cells vary in size and shape, depending on the function (PIRCH and Greven, 1994). In Dactylobiotus dispar the midgut epithelium is also composed only of epithelial cells, which as structurally different, forming three distinct regions: pro-, meso- and metamesenteron (ZА̨BCZYK, 2000). Our studies revealed that during encystation, when the midgut lumen is devoid of nourishment, the midgut epithelium shrinks, becomes pleated and contractile, so it is difficult to distinguish all the above-mentioned midgut regions. It is also difficult to identify crescent-shaped cells of promesenteron described in $D$. dispar by $\mathrm{Z}_{\mathrm{A} B C Z Y K}$ (2000) and in some other water bears (Bertolani, 1970; Greven, 1976; Pirch and Greven, 1994).

ZABCZYK (2000) observed small amounts of lipid droplets in the cytoplasm of midgut epithelial cells in D. dispar, while during encystation (our studies) numerous lipid droplets are gathered. The participation of midgut epithelial cells in lipid storage was described in e.g. Echiniscus testudo (PIrCh and Greven, 1994) and Isohypsibius augusti (GREven, 1976). However it was suggested that lipids were accumulated in epithelial cells of well-nourished specimens (GREVEN, 1976). Nevertheless such numerous lipid droplets, Golgi apparatus and cisterns of endoplasmic reticulum accumulated in the cytoplasm of midgut epithelial cells of analyzed species during encystation suggest the intense synthesis of lipids, which are used in case of absence of food. WeglararsKa (1957) described the accumulation of lipid droplets and glycogen in the storage bodies during encystation of $D$. dispar. She states that cysts are formed in order to survive a period 
of hunger and when this period is prolonged, entire storage bodies might be resorbed. Just encysted specimens have much more lipids and glycogen than active specimens.

Accumulation of numerous small vesicles opening into the midgut lumen, vesicles with electron dense content and vacuoles, which might be treated as the multivesicular bodies, seems to confirm the participation of the midgut epithelium in gathering nutritive substances (ZĄBCZYK, 2000). During encystation the midgut epithelium together with storage bodies must play a role in accumulation of lipids and polysaccharides, which are supplied to all tissues and organs (Węglarska, 1957). Numerous Golgi complexes and cisterns of endoplasmic reticulum suggest intense processes of their synthesis. The small number of mitochondria implies slow transport of substances, which are accumulated in vesicles and multivesicular bodies. However, exocytosis is observed even during the encystation and probably makes it possible to remove products of digestion from the cytoplasm to the midgut lumen.

\section{ULTRASTRUKTURA NABŁONKA JELITA ŚRODKOWEGO NIESPORCZAKA DACTYLOBIOTUS DISPAR (TARDIGRADA: EUTARDIGRADA) W TRAKCIE ENCYSTATCJI.}

Niesporczaki należą do bezkręgowców, które zdolne są przeżyć niekorzystne warunki środowiska, między innymi dzięki encystacji. Dla wielu gatunków opisana została histoliza narządów wewnętrznych w trakcie encystacji, podczas gdy proces ten nie zachodzi u $D$. dispar. Jak wiadomo nabłonek jelita środkowego odpowiada za trawienie, sekrecję, absorpcję, a nawet za osmoregulację. W trakcie encystacji osobników $D$. dispar procesy związane z trawieniem ulegają spowolnieniu, a światło jelita pozbawione jest mas pokarmowych. Liczne krople lipidowe, pęcherzyki oraz ciała wielopęcherzykowe gromadzone są na terenie cytoplazmy komórek epitelialnych. Nabłonek jelita środkowego u encystowanych osobników D. dispar został opisany na poziomie mikroskopii elektronowej.

\section{REFERENCES}

Avdonina, A.M., Biserova, N.M., Bertolani, R., Rebecchi, L., 2007: Ultrastructure of the digestive system of Ramazzottus tribulosus and Macrobiotus richtersi (Eutardigrada) in relation with diet. J. Limnol., 66 (Suppl. 1): 5-11.

Bertolani, R., 1970: Mitosi somatiche e costanza cellulare numerica nei Tardigradi. Atti della Accademia Nazionale dei Lincei Rendiconti Classe di Scienza Fisiche Matematiche e Naturali., 48: 739-742.

Dewel, R.A., Roush, B.G., Dewel, W.C., 1988: Fine structure of the midgut cells of the heterotardigrade Echiniscus viridissimus. Am. Zool., 28: 149A.

Dewel, R.A., Nelson, D.R., Dewel, W.C., 1993: Tardigrada. In: Microscopic Anatomy of Invertebrates. Vol. 12: Onychophora, Chilopoda and Lesser Protostomata. Wiley-Liss, Inc.: 143-183. 
Greven, H., 1976: Some ultarstructural observations on the midgut epithelium of Isohypsibius augusti (Murray, 1907) (Eutardigrada). Cell Tissue Res., 166: 339-351.

Heinis, F., 1910: Systematik und Biologie der Moosbewohnenden Rhizopoden, Rotatorien und Tardigraden usw. Archiv. Hydrobiol. Planktonkund., 5: 1-115.

Kinchin, I.M., 1994: The Biology of Tardigrades. Portland Press, London.

Kristensen, R.M., 1976: On the fine structure of Batillipes noerrevangi Kristiensen 1976. I. Tegument and moulting cycle. Zool. Anz., 197: 129-150.

MAY, R.M., 1948: La vie der Tardigrades. Histories Naturelles. Paris.

Murray, J., 1907: Encystment of Tardigrada. Tr. R. Soc. Edinburgh.

Pigoń, A., Węglarska, B., 1953: The respiration of Tardigrada: A study of animal anabiosis. Bull. L'Acad. Pol. Sc., 1: 69-72.

Pirch, J., Greven, H., 1994: Fine structure of the midgut and the hindgut in Echiniscus testudo Doyère (Heterotardigrada). Zool. Anz., 232: 161-175.

SzymańskA, B., 1995: Encystment in the tardigrade Dactylobiotus dispar (Murray 1907) (Tardigrada: Eutardigrada). Zool. Polon., 40/1-4: 91-102.

Węglarska, B., 1957: On the encystation in tardigrada. Part first. Zool. Polon., 8: 315 325.

ZĄBCZYK, I., 2000: Ultrastructural studies on the midgut of Dactylobiotus dispar (MurRAY, 1907) (Macrobiotidae, Eutardigrada). Acta Biol. Cracov. Ser. Zool., 42: 9-16. 